\title{
Opinions of Quebec parents and vaccinators on the usefulness of chickenpox vaccine
}

\author{
Nicole Boulianne inf $\mathrm{MSc}^{1}$, Bernard Duval MD MPH FRCPC ${ }^{1}$, Gaston De Serres MD PhD ${ }^{1}$, \\ Geneviève Deceuninck MD MSc ${ }^{1}$, Marc Dionne MD MPH ${ }^{1}$, John Carsley MD MSc FRCPC ${ }^{2}$, \\ Louise Valiquette MD MSc FRCPC ${ }^{2}$, Richard Massé MD MSc FRCPC ${ }^{3}$
}

N Boulianne, B Duval, G De Serres, et al. Opinions of Quebec parents and vaccinators on the usefulness of chickenpox
vaccine. Can J Infect Dis 2001;12(3):153-156.

BACKGROUND: A chickenpox vaccine was recently licensed in Canada. Because this vaccine has caused some controversy within the health care profession, studies among Quebec parents and vaccine providers were carried out, surveying their opinions concerning chickenpox vaccination.

METHODS: Three studies among parents of preadolescents, parents of two-year-old children completely or incompletely vaccinated and vaccinators were completed. The studies asked for opinions concerning the usefulness of vaccinating children against chickenpox.

RESULTS: The majority of parents of preadolescents (56\%), and parents of two-year-old children completely (64\%) and incompletely vaccinated $(60 \%)$ favoured chickenpox vaccination. Among vaccinators, $53 \%$ of paediatricians, $37 \%$ of general practitioners and $33 \%$ of nurses considered universal vaccination of young children to be useful. A greater proportion of health care professionals were in favour of a policy of vaccinating groups at risk, such as susceptible adolescents $(86 \%, 75 \%$ and $58 \%$, respectively). There was a positive association between the perceived severity of chickenpox and the potential usefulness of the vaccine.

CONCLUSION: Quebec parents are more favourably disposed to chickenpox vaccine than vaccine providers. In contrast, strategies targeting susceptible groups would be generally well received by health care professionals. A considerable amount of work will be needed to convince vaccinators of the benefits of a universal childhood vaccination against chickenpox.

Key Words: Chickenpox; Immunization programs; Parental opinions; Vaccinator opinions; Varicella vaccine

\section{Opinion des parents et vaccinateurs du Québec sur l'utilité du vaccin contre la varicelle}

HISTORIQUE : Le vaccin contre la varicelle a récemment été autorisé au Canada. Étant donné que ce vaccin a soulevé une certaine controverse au sein de la profession médicale, des études ont été effectuées auprès de parents et de vaccinateurs québécois dont on voulait avoir l'opinion au sujet du vaccin contre la varicelle.

MÉTHODE : Trois enquêtes ont été réalisées, auprès des parents de pré-adolescents, des parents d'enfants de deux ans complètement ou partiellement vaccinés et des vaccinateurs. Par ces études, on cherchait à connaître l'opinion des personnes interrogées sur l'utilité de la vaccination des enfants contre la varicelle.

RÉSULTATS : La majorité des parents de pré-adolescents (56\%) et des parents d'enfants de deux ans complètement (64\%) ou partiellement $(60 \%)$ vaccinés étaient en faveur de la vaccination contre la varicelle. Chez les vaccinateurs, $53 \%$ des pédiatres, $37 \%$ des généralistes et $33 \%$ des infirmières ont considéré la vaccination universelle des jeunes enfants utile. Une pro-

voir page suivante

\footnotetext{
${ }^{1}$ Public Health Research Unit, Centre Hospitalier Universitaire de Québec Research Centre - Pavillon Centre Hospitalier de l'Université Laval, Beauport; ${ }^{2}$ Montréal-Centre Public Health Department, Montréal; ${ }^{3}$ Ministry of Health and Social Services, Québec, Québec Correspondence: Ms Nicole Boulianne, Centre de santé publique de Québec, 2400, rue d'Estimauville, Beauport, Quebec G1E $7 G 9$. Telephone 418-666-7000 ext 235, fax 418-666-2776, e-mail nboulianne@cspq.qc.ca Received for publication January 19, 2000. Accepted June 23, 2000
} 
portion plus grande de professionnels de la santé étaient en faveur d'une politique de vaccination des groupes à risque comme les adolescents sensibles ( $86 \%, 75 \%$ et $58 \%$, respectivement). On a noté un lien favorable entre la gravité perçue de la varicelle et l'utilité potentielle du vaccin.

CONCLUSION : Les parents québécois sont plus favorables à la vaccination contre la varicelle que les vaccinateurs. En revanche, les stratégies axées sur les groupes sensibles seraient en général bien reçues par les professionnels de la santé. Des preuves plus nombreuses ou une formation plus adéquate seraient nécessaires pour convaincre les vaccinateurs des avantages d'une vaccination infantile universelle contre la varicelle.

$I^{\mathrm{n}}$ December 1998, a vaccine against chickenpox was licensed in Canada. The National Varicella Consensus Conference (1) recently recommended the initiation of universal immunization for young children by the year 2005 at the latest and the immunization of susceptible preadolescents until that time. The recommended systematic vaccination has caused some controversy in the medical community, engendering both scepticism (2-4) and enthusiasm (5). One of the possible obstacles to the wide acceptance of this vaccine is the perception among parents and health professionals that chickenpox is a disease without serious consequences for children, that it is even a normal part of childhood (6).

We made use of three different studies among vaccinators and Quebec parents to determine their perceptions of chickenpox and the usefulness of the vaccine.

\section{DATA AND METHODS}

Parents of preadolescents and two-year-old children: The first study group was parents of children aged eight to 10 years in the Quebec City region, who were already enrolled or were being recruited to a study on the long term immunogenicity of the hepatitis B vaccine (7). Approximately onehalf $(50.1 \%)$ of the parents were sent a self-administered questionnaire by mail and then were contacted by telephone. The other half of the parents completed the same questionnaire in the presence of a nurse at the time of recruitment for the hepatitis B study.

The second study group comprised parents of children aged 24 to 27 months from three regions in the province of Quebec (Trois-Rivières, Montreal and Quebec City). The study documented the parents' knowledge, beliefs and attitudes concerning immunization according to the vaccination status of their child at 24 months. Two hundred seventy-nine parents of incompletely vaccinated children and 442 parents of completely vaccinated children were selected from the regional vaccination registers and were sent a self-administered questionnaire by mail.

Vaccinators: All paediatricians, general practitioners and nurses administering vaccines to young children in Quebec were sent a self-administered questionnaire by mail, which asked about their knowledge, beliefs and practices concerning immunization. A few questions dealt specifically with chickenpox.

The distribution and follow-up of the questionnaires for the parents of two-year-old children and vaccinators were carried out according to the Dillman method (8).

Variables and statistical analyses: The dependent variable in all analyses was the subject's opinion on the usefulness of the chickenpox vaccination. This information was collected using a four-point Likert scale based on the subject's agreement with statements concerning the usefulness of the chickenpox vaccination: 'total disagreement', 'somewhat disagreement', 'somewhat agreement' or 'total agreement'. For analyses, these answers were divided into either 'agreement' or 'disagreement'.

The independent variables differed among studies. Among parents of preadolescents, the data collected were limited to the history of chickenpox and the ensuing medical care. Among parents of two-year-old children and vaccinators, data collected included demographic information, the perception of vaccines in general, the fear of administering (vaccine providers) or receiving (parents) two shots on the same day, the perception of the potential severity of chickenpox and the frequency of complications. Parents of two-year-old children were also asked about the history of chickenpox in their children, the presence of complications in their children and their satisfaction concerning the information received about vaccine preventable diseases or about possible reactions to vaccines.

Proportions were compared by the $\chi^{2}$ test or the Fisher exact test. Multivariate analyses were carried out with logistic regression.

\section{RESULTS}

Of the 2255 parents of eight- to 10-year-old children, $99 \%$ agreed to participate. The participation rate was $54 \%$ (722 of 1330) for the parents of two-year-old children and did not vary according to the vaccination status; one child was excluded because his vaccination status was unclear. The participation rate for the 3173 vaccinators was $74 \%$ (377 of 509 ) for paediatricians, $57 \%$ (820 of 1431) for general practitioners and $85 \%$ (1045 of 1233 ) for nurses.

More parents than vaccinators agreed about the usefulness of the vaccine $(\mathrm{P}<0.001)$ (Table 1$)$. Among vaccinators, paediatricians clearly favoured the chickenpox vaccine more than general practitioners or nurses $(\mathrm{P}<0.001)$.

Parents of preadolescents: Ninety-one per cent of the parents of preadolescent children reported a history of chickenpox by age 10 years, with $47 \%$ reporting medical consultation. The vaccine was viewed as 'useful' more often by parents whose children had not yet acquired chickenpox than by those whose children had already suffered from chickenpox (75\% compared with $57 \%, \mathrm{P}<0.001)$. The vaccine was considered useful more often by parents whose children had to consult a physician than by those who did not (65\% compared with $49 \%, \mathrm{P}<0.001)$. These comparisons excluded parents who had 'no opinion' or who did not answer the question.

Parents of two-year-old children: Almost half (49\%) of parents of two-year olds were somewhat or completely in agreement with the statement: "Chickenpox is a disease that can 
TABLE 1

Overall opinion of parents and vaccinators regarding the usefulness of chickenpox vaccine

\begin{tabular}{|c|c|c|c|}
\hline & $\begin{array}{l}\text { Agreement } \\
(\%)^{*}\end{array}$ & $\begin{array}{l}\text { Disagreement } \\
(\%)^{+}\end{array}$ & $\begin{array}{c}\text { Do not } \\
\text { know (\%) }\end{array}$ \\
\hline \multicolumn{4}{|l|}{ Parents of two-year-old children } \\
\hline $\begin{array}{l}\text { Completely vaccinated } \\
(\mathrm{n}=446)\end{array}$ & $\begin{array}{c}65 \\
(30 ; 35)\end{array}$ & $\begin{array}{c}25 \\
(18 ; 7)\end{array}$ & $10 \%$ \\
\hline $\begin{array}{l}\text { Incompletely vaccinated } \\
(\mathrm{n}=276)\end{array}$ & $\begin{array}{c}60 \\
(27 ; 33)\end{array}$ & $\begin{array}{c}30 \\
(18 ; 12)\end{array}$ & $9 \%$ \\
\hline $\begin{array}{l}\text { Parents of preadolescents } \\
(\mathrm{n}=2227)\end{array}$ & $\begin{array}{c}56 \\
(18 ; 38)\end{array}$ & $\begin{array}{c}39 \\
(26 ; 13)\end{array}$ & $5 \%$ \\
\hline \multicolumn{4}{|l|}{ Vaccinators } \\
\hline $\begin{array}{l}\text { Paediatricians } \\
(\mathrm{n}=294)\end{array}$ & $\begin{array}{c}53 \\
(22 ; 31)\end{array}$ & $\begin{array}{c}44 \\
(32 ; 12)\end{array}$ & $3 \%$ \\
\hline $\begin{array}{l}\text { General practitioners } \\
(\mathrm{n}=772)\end{array}$ & $\begin{array}{c}37 \\
(10 ; 27)\end{array}$ & $\begin{array}{c}59 \\
(43 ; 16)\end{array}$ & $4 \%$ \\
\hline $\begin{array}{l}\text { Nurses } \\
\qquad(\mathrm{n}=993)\end{array}$ & $\begin{array}{c}33 \\
(12 ; 21)\end{array}$ & $\begin{array}{c}58 \\
(33 ; 25)\end{array}$ & $9 \%$ \\
\hline
\end{tabular}

*Total agreement; somewhat agreement; ${ }^{\dagger}$ Somewhat disagreement; total disagreement

sometimes be serious"; $34 \%$ disagreed with this statement, and $17 \%$ did not know or did not answer. One-third of the respondents $(33 \%)$ reported that their two-year-old children had already had chickenpox, and $2 \%$ said that their children had suffered a complication. In multivariate analysis, the perception of the potential severity of chickenpox was the variable most strongly associated with the opinion that the chickenpox vaccine was useful (Table 2). The fear of having two injections on the same day did not change these parents' opinions of the vaccine's usefulness.

Vaccinators: Depending on their professional training, between $33 \%$ and $53 \%$ of vaccinators felt that the systematic vaccination of young children against chickenpox would be appropriate (Table 1). Most vaccinators agreed with the targeted use of the vaccine for children at greater risk of complications; $93 \%, 94 \%$ and $76 \%$ of paediatricians, general practitioners and nurses, respectively, were in favour of that policy. The vaccination of susceptible adolescents was favoured by $86 \%, 75 \%$ and $58 \%$ of these groups, respectively (Figure 1), while the vaccination of susceptible women of child-bearing age was favoured by $85 \%, 84 \%$ and $68 \%$, respectively. For every group at risk, nurses were the least convinced of the vaccine's usefulness.

Only $15 \%$ of paediatricians, $6 \%$ of general practitioners and $10 \%$ of nurses considered the complications of chickenpox to be frequent, but a much larger proportion of these professionals (83\%, 78\% and 55\%, respectively) knew that these complications could occasionally be serious. These two variables were the most strongly associated with a favourable opinion toward the usefulness of the chickenpox vaccine (Table 3).

\section{DISCUSSION}

Although these results are derived from three studies carried out independently with different groups, they allow us to estimate the major trends.
TABLE 2

Variables associated with a perception* of the usefulness of a chickenpox vaccine among parents of two-year-old children (multivariate analysis, $\mathrm{n}=638$ )

\begin{tabular}{|c|c|c|}
\hline Variables & $\begin{array}{l}\text { Odds } \\
\text { ratio }\end{array}$ & $95 \% \mathrm{Cl}$ \\
\hline $\begin{array}{l}\text { In agreement with "chickenpox is a disease } \\
\text { that can sometimes be serious" }\end{array}$ & 7.5 & 4.9 to 11.5 \\
\hline $\begin{array}{l}\text { In disagreement with "I believe that a } \\
\text { hygienic lifestyle can eliminate the need for } \\
\text { vaccination" }\end{array}$ & 3.2 & 1.6 to 6.7 \\
\hline Mother's schooling at secondary level or lower & 2.1 & 1.3 to 3.4 \\
\hline Age under 30 years & 1.9 & 1.2 to 3.0 \\
\hline $\begin{array}{l}\text { Not aware of unfavourable opinions about } \\
\text { vaccination in the media }\end{array}$ & 1.8 & 1.2 to 2.8 \\
\hline Lack of childhood history of chickenpox & 1.7 & 1.1 to 2.6 \\
\hline $\begin{array}{l}\text { Parent of a child whose vaccination booklet } \\
\text { was complete at the age of } 24 \text { months }\end{array}$ & 1.2 & 0.8 to 1.8 \\
\hline
\end{tabular}

*Parents answered that they were somewhat or completely in agreement with the statement: "If a vaccine against chickenpox were available in Quebec, I believe it would be useful to offer it to Quebec children in the context of a regular vaccination program"

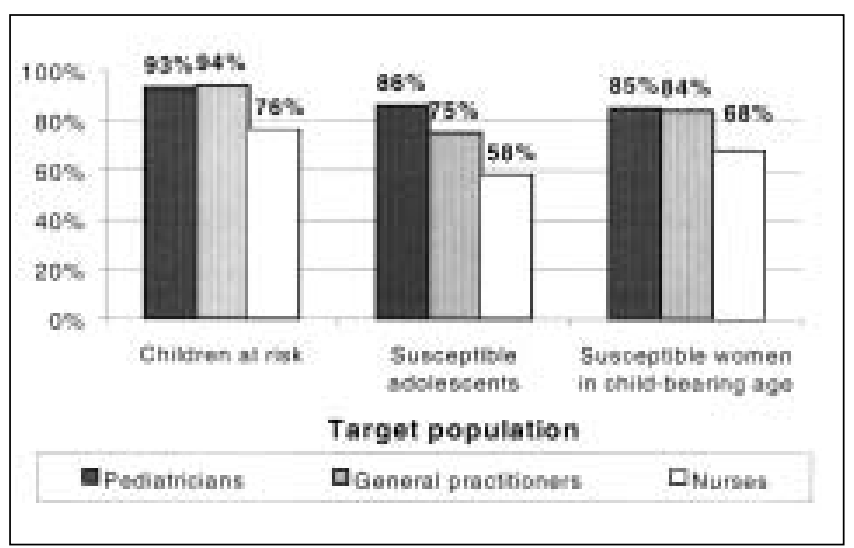

Figure 1) Proportion of vaccinators totally in agreement and somewhat in agreement with the use of a vaccine against chickenpox, according to target population

More parents than vaccinators considered varicella vaccination to be useful. It is interesting to note that the same opinion was found among the three groups of parents; it was expected that the parents of incompletely vaccinated children would have a less favourable opinion and that the parents whose children were to participate in the hepatitis B study would have a more favourable opinion about the usefulness of the varicella vaccine. It is likely that this opinion adequately represents that of the general population. Moreover, these estimates are similar to those reported in another study carried out among parents of Quebec children (9).

There was not great enthusiasm for this vaccine among vaccinators. Barely half of the paediatricians considered the vaccine to be useful, while a clearly smaller proportion (33\%) of nurses found it to be useful. These results are comparable with observations made in Canada at the beginning of 1999 by the Laboratory Centre for Disease Control, which found 
TABLE 3

Variables associated with a perception* of the usefulness of a chickenpox vaccine among vaccinators (multivariate analysis, $n=1899$ )

\begin{tabular}{|c|c|c|}
\hline Variables & $\begin{array}{l}\text { Odds } \\
\text { ratio }\end{array}$ & $95 \% \mathrm{Cl}$ \\
\hline $\begin{array}{l}\text { Believe that the complications of chickenpox } \\
\text { are frequent }\end{array}$ & 4.0 & 2.8 to 5.7 \\
\hline $\begin{array}{l}\text { Believe that the complications of chickenpox } \\
\text { can be serious }\end{array}$ & 2.5 & 1.9 to 3.1 \\
\hline Age 40 to 49 years ${ }^{\dagger}$ & 1.4 & 1.2 to 1.8 \\
\hline Age 50 years or older ${ }^{\dagger}$ & 2.7 & 2.1 to 3.5 \\
\hline $\begin{array}{l}\text { Completely convinced of the usefulness of the } \\
\text { vaccines in the existing vaccine calendar }\end{array}$ & 1.7 & 1.3 to 2.3 \\
\hline $\begin{array}{l}\text { Believe themselves to be moderately or } \\
\text { poorly informed of the reasons behind the } \\
\text { latest modifications to the vaccine calendar }\end{array}$ & 0.7 & 0.6 to 0.9 \\
\hline
\end{tabular}

*Vaccinators answered that they were somewhat or totally in agreement with the statement: "If a vaccine against chickenpox were available in Quebec, I think it would be useful to offer it to Quebec children in the context of a regular vaccination program $" ;{ }^{\dagger}$ Compared with respondents under 40 years of age

that $61 \%$ of the paediatricians surveyed were favourable toward a policy of universal childhood vaccination with the present vaccine, as were $36 \%$ of general practitioners and $28 \%$ of nurses (10).

Similar to previous studies $(6,11)$, we found that there was a strong association between the perception of the potential seriousness of the disease and an opinion in favour of universal vaccination. This may explain why the vaccination of high risk populations was favoured by the majority of all groups of vaccinators in Quebec (although nurses were clearly the least convinced group). A vaccination strategy targeting susceptible preadolescents, as was recommended during the National Varicella Consensus Conference (1), was perceived more positively by vaccinators (58\% to $86 \%$ ) than infant vaccination ( $33 \%$ to $53 \%$ ). Such a strategy would probably be well accepted by the public, because $75 \%$ of parents of eight- to 10-year-old children who had not contracted chickenpox believed that vaccination would be useful.

The fact that a large proportion of vaccinators, particularly nurses, are not convinced of the possible complications of varicella in young children suggests that there is a need for the wide dissemination of information among health professionals if we hope to promote the universal use of the vaccine among young children. It should be stressed that the present information was collected in the spring of 1998, before the approval of the vaccine in Canada and the publicity surrounding its introduction. Vaccinators' opinions may have evolved in favour of the vaccine since that time.

\section{CONCLUSIONS}

Only a relatively small proportion of Quebec vaccinators considered universal vaccination against chickenpox to be useful. If such a program is to be introduced without obstruc- tion, it will be necessary to inform and convince many of these doubters. Vaccinators who are well informed on the justification for such new recommendations may more easily approve of them and eventually adopt them (12). Given the great influence that these professionals have on the choices parents make concerning vaccination $(13,14)$, it will be necessary to provide them with information to respond to parents' questions. This structured, information-rich approach for health professionals will be a prerequisite for any successful chickenpox vaccination program in the province of Quebec.

ACKNOWLEDGEMENTS: These studies were financially supported by the Division of Immunization, Bureau of Infectious Diseases, Laboratory Centre for Disease Control, Health Canada; the Ministère de la Santé et des Services sociaux du Québec; Merck Frosst; and SmithKline Beecham Pharmaceuticals. The authors acknowledge and express thanks to Colette Couture, France Lavoie, Fernand Guillemette, Marjolaine Guay, Sophie Auger, Louis Rochette, Nathalie Laflamme, Martyne Nadeau and Claude Boulianne for their valuable contribution to this project. The authors also thank Brian Ward for revising the manuscript.

\section{REFERENCES}

1. Proceedings of the National Varicella Consensus Conference. Can Commun Dis Rep 1999;25(Suppl 5):1-29.

2. Stein ND. Recommendations for varicella vaccine. Pediatrics 1995;96:545.

3. Ross LF, Lantos JD. Immunization against chickenpox. Br Med J 1995;310:2-3.

4. Spingarn RW, Benjamin JA. Universal vaccination against varicella. N Engl J Med 1998;338:683.

5. Meissner HC. Universal vaccination against varicella. N Engl J Med 1998;338:684

6. Schaffer SJ, Bruno S. Varicella immunization practices and the factors that influence them. Arch Pediatr Adolesc Med 1999;153:357-62.

7. Duval B, Boulianne N, De Serres G, et al. Comparative immunogenicity under field conditions of two recombinant hepatitis B vaccines in 8-10 year-old children. Vaccine 2000;18:1467-72.

8. Dillman DA. Mail and Telephone Surveys - The Total Desing Method. New York: John Wiley \& Sons, 1978:325.

9. De Wals P, Blackburn M, Guay M, Bravo G, Blanchette D, Douville-Fradet M. Fardeau de la varicelle pour les familles au Québec. Enquête auprès d'un échantillon représentatif des ménages. Sherbrooke: Université de Sherbrooke, 1999.

10. Bentsi-Enchill A, Tam T. Survey on the use of varicella vaccine in Canada: Preliminary results. Division of immunization, Bureau of Infectious Disease, Laboratory Centre for Disease Control, 1999.

11. Newman RD, Taylor JA. Reactions of pediatricians to the recommendation for universal varicella vaccination. Arch Pediatr Adolesc Med 1998;152:792-6.

12. Pathman DE, Konrad TR, Freed GL, Freeman VA, Koch GG. The awareness-to-adherence model of the steps to clinical guideline compliance. Med Care 1996;34:873-89.

13. Taylor JA, Darden PM, Slora E, Hasemeier CM, Asmussen L, Wasserman $R$. The influence of provider behavior, parental characteristics, and a public policy initiative on the immunization status of children followed by private pediatricians: A study from pediatric research in office setting. Pediatrics 1997;99:209-15.

14. Taylor JA, Cufley D. The association between parental health beliefs and immunization status among children followed by private pediatricians. Clin Pediatr (Phila) 1996;35:18-22. 


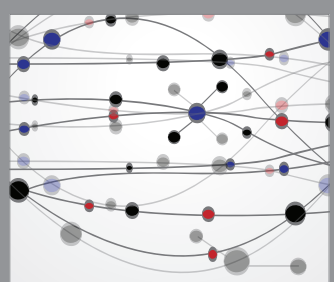

The Scientific World Journal
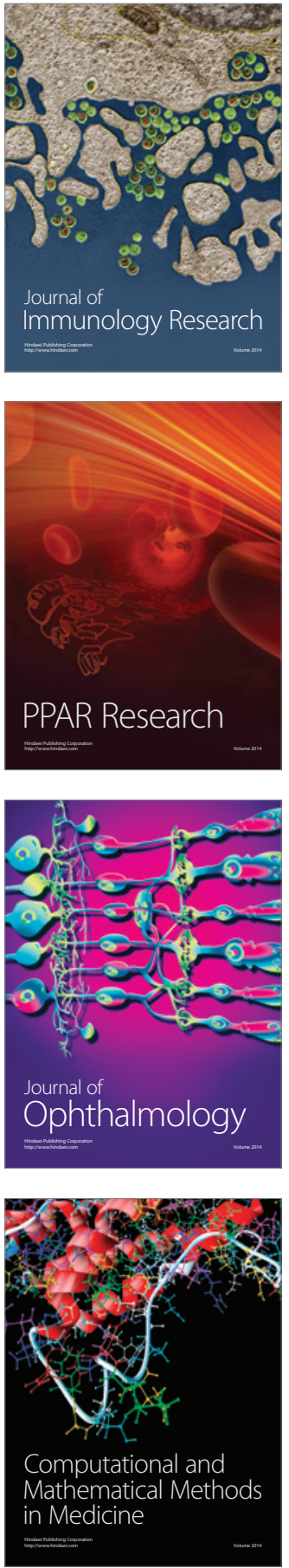

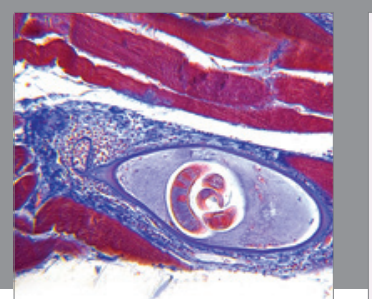

Gastroenterology Research and Practice

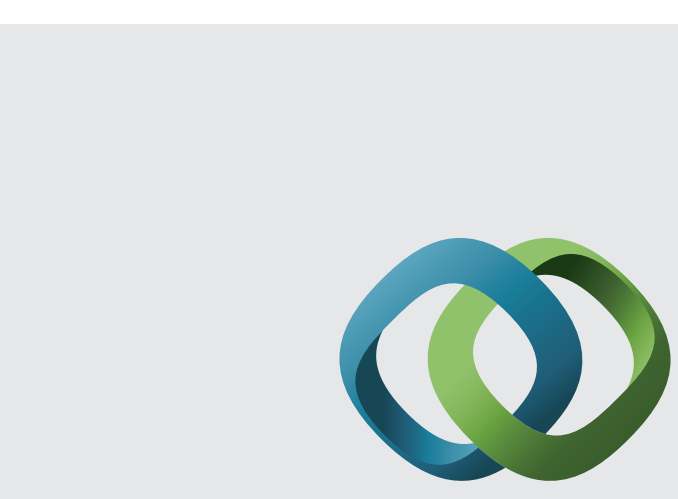

\section{Hindawi}

Submit your manuscripts at

http://www.hindawi.com
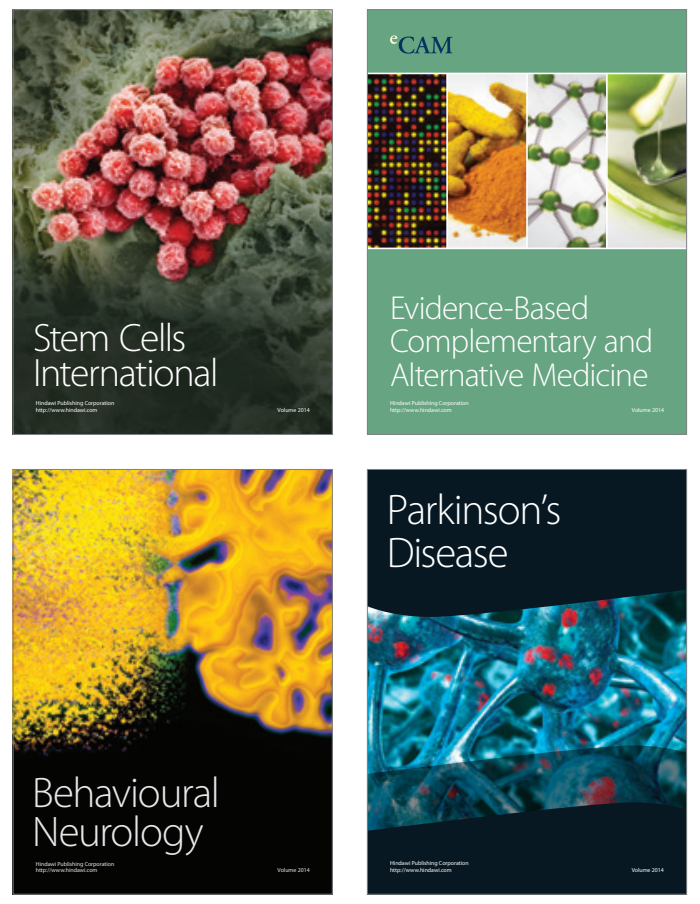
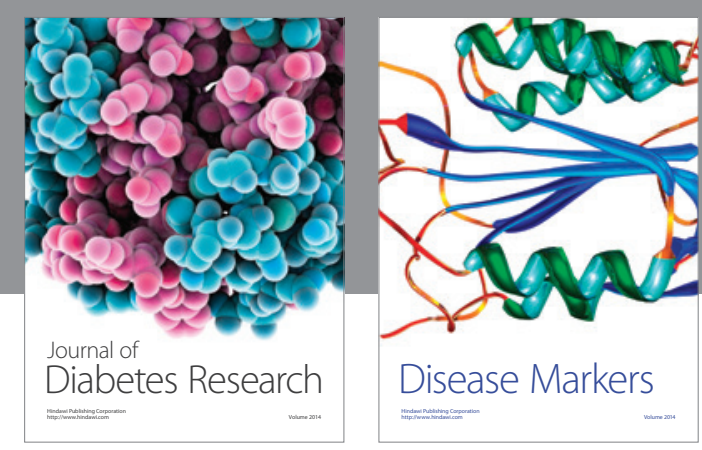

Disease Markers
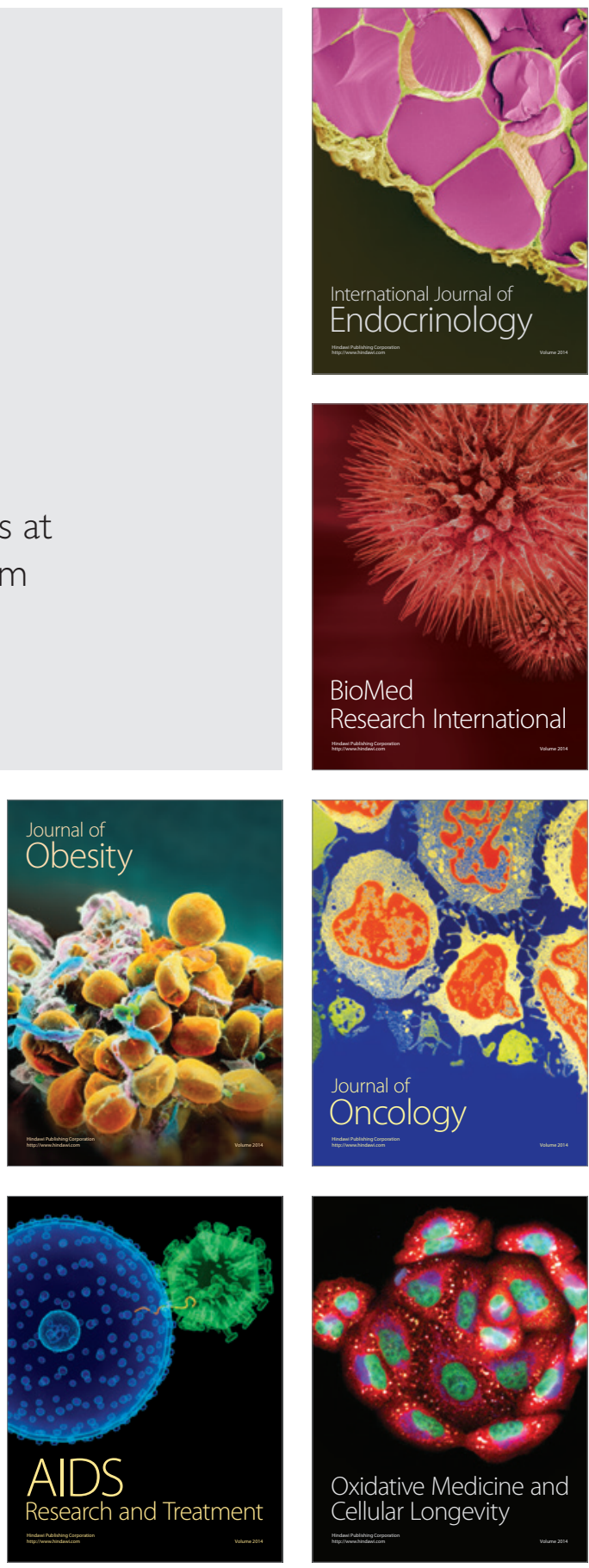